\title{
A Literature Study: The Concept of Smart City between Municipal vs. Regency (Between Efficiency, Habitability, and Local Wisdom)
}

\author{
Tb. Ai Munandar ${ }^{1}$, Harsiti $^{2}$, Abdul Malik $^{3}$, Kurnia Satriawan ${ }^{4}$, Andi Afandi $^{5}$ \\ \{tbaimunandar@gmail.com ${ }^{1}$, harsiti@yahoo.com², kangdoel2002@gmail.com ${ }^{3}$ \} \\ Informatics Dept., Universitas Serang Raya ${ }^{1}$, Information Systems Dept., Universitas Serang Raya ${ }^{2}$, \\ Communication Science Dept., Universitas Serang Raya ${ }^{3}$, Badan Perencanaan Pembangunan Daerah \\ Kabupaten Pandeglang ${ }^{45}$
}

\begin{abstract}
The smart city concept is one of the important alternatives in the effort to solve various problems in the urban area. However, provincial administration in several countries including Indonesia is divided into two categories: municipality and regency. There are problems arising when smart city concept implemented in the regency because the municipality and the regency have the significant of different characteristics. The blueprint preparation of smart city concept should be prepared by taking into the local wisdom possesed by the region, especially for regency that is different from the municipality. Thus, the implementation of the concept is adapted to the characteristics and needs of the region. The result shows that smart cities can be carried out as efficiently as possible in terms of technology implementation. Besides that the smart city that is built must prioritize the concept of livable for its inhabitants without ignoring the local wisdom they have.
\end{abstract}

Keywords: smart city, municipality, regency, characteristic differences, local wisdom.

\section{Introduction}

Smart city is a concept with broad and various definitions [1], [2], [3]. Therefore, specifically it has no particular definition which can even be said to be vague [4], [5]. Smart city focuses more on resolving urban issues, but does not thoroughly target the solutions beyond the city circle. In fact, the city residents have a variety of characters, culture, lifestyle, customs and other aspects that often do not appear in the discussion of smart city. In the concept of smart city, the use of technology to support the creation of smart city, however, becomes the ultimate goal. Various interests' of the smart city supporting devices providers' vendors even actually have more role than to build the characters of the smart city itself. Instead of establishing to be a smart city, the people themselves do not become wise and intelligent.

The concept of smart people is often the last option when policy makers attempt to apply the concept of smart city in their region. Many experts agree on the table that smart people have a very important role in building a smart city. But in fact, it is the use of ICT and other supporting technologies that even dominate. Ultimately, society may become just a victim of technological advances that create new problems both socially and psychologically. Communities are forced to follow the style of government in organizing and managing cities to be called smart cities according to a vision that even the people themselves may never be familiar with.

ICCSET 2018, October 25-26, Kudus, Indonesia

Copyright () 2018 EAI

DOI 10.4108/eai.24-10-2018.2280608 
The debate over which is more important about the six components of smart city to be implemented first, is still unanswered. Each component is indeed interconnected with each other. Some experts even urge new smart city models based on a few components plus other support elements as its enablers. The direction of smart city concept that put the smart people in it also ended in the fulfillment and development of technology solely on the pretext of helping to facilitate the access and service of city residents. Several services developed and claimed to be included in the part of smart people, for example, the development of real-time virtual connections to help people with disabilities interact with others [6], the development of tools for people who have difficulty thinking, using language and even memory loss [7], utilization of IoT for the provision of health and social services for elderly urban residents [8] as well as the development of intelligent aids for the blind [9], [10]. The orientation of smart people also ultimately ends with the fulfillment of the needs of technology alone. The concept of smart city by promoting the characteristics, culture, and lifestyle of the city residents has never been an important concern in the concept of smart city.

The facts in the field show that in some parts of the world a region is usually grouped into two types of territories that enter territorial with the category of regency and municipal categories. Differences characteristics of a territory have not been able accommodated by the concept of smart city is growing. During this time the concept of smart city more widely applied to the region within the category of city/municipality. Meanwhile, the terminology of the regency with the city/municipality is two different things, even when viewed in terms of geography, population, socio-cultural, income to government structure, both have a fairly basic difference.

This study is an attempt to examine further the direction of the concept of smart city which is currently widely developed in various parts of the world. This effort was made to find out the possibility of developing an intelligent city model that not only oriented to the fulfillment of technology alone but also must be able to accommodate the customs, culture, behavior and local wisdom of each city that will and are implementing smart city. In addition, this study was conducted in an attempt to identify whether perhaps the concept of smart city does not only apply to areas with municipal categories but also for areas with categories of regency. This research was conducted with a literature review approach to explore how the concept of smart city can be applied efficiently, make the city livable and prioritize the local wisdom possessed by a region.

\section{Literature Review}

This section divides the discussion into two sub-sections, the first is definition of the concept of smart city and second is smart city implementations at this time. The concept of smart city discussed puts forward the opinions of researchers and experts, not focusing on one definition because the researcher believes that the definition of smart city is not final. In the second sub-section, the researcher presents several smart city implementations for a decade. The aim is to see the direction of the concept of smart city that is currently widely used in various parts of the world. 


\subsection{Smart city concept}

Smart city is becoming a worldwide trend recently. This concept is believed to be able to solve various problems of the city due to the massive urbanization of the population from rural to urban [11] so it is expected to improve the quality of life of the community [12]. However, the actual definition of smart city is still vague [13] and there is no standard consensus about the definition of smart city because understanding can be different from one country to another, even in one country with some territorial territory may be different [14]. Some claim that smart city is an innovation in urban governance [15], [16]. Some others are seeing that smart city is a developmental effect and the process of utilizing ICT architecture and technology [17], [18], [19], [20], [21]. In general, smart city has six main characteristics which then gave birth to many derivatives of smart solutions that are more pragmatic. The six characteristics are smart economy, smart people, smart government, smart mobility, smart environment and smart living [22], [23], [24]. Each characteristic represents alternative solutions that can be implemented to build smart cities. The selection of which components are more important and main to be implemented is generally left to the policy and readiness of each region based on the analysis of the availability of resources and devices.

\subsection{Smart city current implementation}

The concept of smart city that is currently adopted by some countries and cities put forward the concept of digitalization of activities or service process to city residents. Some of the conveniences offered cannot be separated from the role of technology, especially ICT to the Internet of Things [25]. Various applications have been developed to support smart cities, such as the development of intelligent systems for optimization of energy allocations [26], [27] monitoring landfills capable of reducing urban waste management costs [28], electronic public service-based complaints services [29] lighting control with remote control systems [30], [31], intelligent control of city traffic lights [32], [33], [34], analysis and development of intelligent systems in the field of transportation [35], [36], [37], [38] as well as the development of a city bike rental sharing system that is able to minimize city noise [39].

\section{Research Methodology}

The research method used was descriptive historical in which the research conducted is a descriptive analysis study by utilizing data sources in the form of research results and thoughts of previous researchers to produce a new study in the same field. This research began with discussion and identification of problems related to the implementation of smart city in various places. The preliminary study was conducted with literature review of several recent research papers. The next stage was classifying the literature review into two main concepts, namely the review of smart city concept and its current implementation. The formulation of the final objective of the study is the possibility of whether the concept of smart city can be applied in the region with the regency category discussed in the sub-chapter of research findings. 


\section{Research Findings}

\subsection{Smart city: between efficiency and habitability}

The concept of smart city should make the inhabitants of the city as the center of intelligence itself so that awaken a civilization that is really in accordance with the principle of intelligence. Not just to make an object to be smart, while the city community has not been able and not ready to go to a smart city. Many countries and even cities in different parts of the world implement the concept of smart city only on the side of technology development and the development of an ICT-based system. Although several of them also focus on how to organize the city with the principles of governance that can make the residents comfortable, that does not have to be merely about the application of technology, but just a very little.

The characteristics of smart city basically contain six aspects: smart economy, smart governance, smart environment, smart people, smart mobility and smart living. Each of these characteristics is then downgraded into several sub-activities that can support the creation of smart cities. Table 1 shows the mind map of the six sub-components of intelligent city characteristics.

Table 1. Six smart city characteristics [11].

\begin{tabular}{ll}
\hline Six Characteristics & Most 3 Indicators \\
\hline Smart Economy & - Enterprenership and Innovation (14) \\
& - Economic Vitality and Planning (13) \\
Smart Environment & - Enoductivity (6) \\
& - Monitoring Pollution Degree (7) \\
Smart Government & - ICT and E-Government (13) \\
& - Transparent governance and open data (12) \\
Smart Living & - Participation in decision making (6) \\
& - Healthcare Services (18) \\
Smart Mobility & - Housing Quality (12) \\
- Public Transportation System (33) & - ICT Infrastructure (19) \\
Smart People & - Inter)national accessibility (5) \\
& - Social and Cultural Plurarity (15) \\
& - Creativity (6) \\
\hline
\end{tabular}

Looking at the mind map as in Table 1, it is very clear that the purpose of the smart city concept is very noble. Make a city more efficient and livable. Language is efficient, meaningful or appropriate in doing something. This means that any work done does not waste time, effort and money. Another meaning of efficient is being able to perform the task properly and accurately, efficiently and effectively. Referring to the efficient definition, then the concept of 
smart city will be closer to the second definition. Therefore, the efficient referred to in smart city is the utilization and empowerment of resources optimally to support all the needs of city residents. Of course the empowerment in question should pay attention to the concept of precise, thorough, efficient and targeted. Thus the intelligent city that was built really able to facilitate and provide excellent service for its inhabitants so that materialize a habitable city. Smart City is analogous to being a city that is able to control, control and integrate all of its infrastructure in order to optimize its utilization. Larger in the planning of prevention of damage, prevention of city problems that arise both crime and other crime.

In addition, the meaning of habitable can be seen by the following definition. Habitable consists of two syllables namely "decent" and "habitable". Worthy means worthy, reasonable or proper. The second syllable is habitation which means place or dwelling. Thus habitable in language can be interpreted as a place that deserves to be occupied or inhabited. The feasibility can be seen in many ways. If it refers to the six smart city characters, then it is worth living, of course, should pay attention to the six principles where city residents deserve smart and smart living education, earn livelihood and provide smart economy, living cultured, equipped with adequate supporting facilities and infrastructure (smart living and smart environment) with excellent governance (smart governance) accompanied by ease of association and communicate between and other intra-city inhabitants (smart mobility).

So what happens now? The new smart city is struggling with the efficiency stage of resources. Many urban residents are forced to comply with the rules and the use of technology, especially ICT in accessing various resources in their city. ICT that should act as an enabler in the concept of smart cities, often switching functions into important components that should not be lost. Like it or not, believe it or not that's the fact that happened.

As evidence, in the territory of Ningbo and Shanghai, People's Republic of China, the implementation of smart city put forward the use of ICT to reach the smart city. Many ICTbased systems are built for efficient use of resources there [40], [41]. Other countries such as Arab also put forward the concept of ICT for the implementation of smart city. Big data analysis techniques and Internet of Things have become core in the Arab countries for smart city implementation [42]. India implemented the concept of intelligent solutions by developing ICTbased smart city models and technology development [43]. Unlike India, in Seoul, smart city models have three main pillars, ICT and other technologies supported by the concept of smart users [44]. Berlin a little trying to make the concept of a smart city rather put forward the term livable with the concept of smart house, smart economy, smart infrastructure, smart mobility, public safety and smart administration [45]. In a developing country like Indonesia with a diversity of people and cultures, again ICT becomes an important part in the effort to implement smart city concept. This is evident from some of the smart city models developed in the country [46].

Smart city is currently developing at an existing stage of resource efficiency, especially in the utilization and development of technology. The concept of a habitable city is still out of reach. Habitable city should not be only seen from how sophisticated equipment and technology used by a city, but also must pay attention to the concept of the intelligence of its inhabitants, an environment that is able to bring the culture that makes its inhabitants cultured, civilized and more humane. Not just technology users who alienated from the environment or even alienated among the community of other residents.

4.2 Smart city for regency area with local wisdom base, is it possible? 
The concept of smart city that is currently widely adopted in various regions of the world more widely implemented in urban areas. In some countries including Indonesia, in fact a region is generally divided into two parts, the first municipality and the two regency. There are many striking differences between municipality and regency. This is to be considered when applying the concept of smart city in a region. Viewed from various aspects, municipality and regency have many striking differences. Therefore, it is important to understand the characteristics of the region before applying the smart city concept. Table 2 shows the different municipality and regency seen from various aspects.

Table 2. The differences of municipality and regency.

\begin{tabular}{ll}
\hline Aspects & Municipality vs Regency \\
\hline Territory & Regency governments have a relatively larger area than municipal \\
& governments. \\
- & More regency have lagging villages than municipality. \\
& - Development budgets allocated to regency are usually larger than \\
& municipality. This is because the problems faced by regency are much \\
& more complex than municipality. \\
- & The municipality has a larger and denser population than the regency. \\
& Because the municipality is usually the goal of urbanization. \\
& - The problems facing municipality related to employment, education, \\
Population & health and other social problems are more complex than regency \\
- & The livelihood of regency residents is mostly engaged in agriculture \\
- & Urban society mostly engaged in services and trade \\
- & The municipal economic activity is more complex than the regency, so \\
& the income level is also greater than the regency \\
Livelihood & - The average value of the region's gross regional domestic product \\
& (GRDP) is usually lower than that of the municipality \\
Economy & - The structure of municipal government is simpler because it is formed \\
& by sub-regency and sub-regency. \\
- & The government structure in the regency consists of sub-regency, sub- \\
& regency, villages and villages \\
- & In terms of education and health, municipality is better than regency. \\
Government Structure & Public service facilities in the municipality is much better than regency \\
\hline &
\end{tabular}

Based on Table 2, it can be seen that the treatment of smart city concept between municipalities should have differences in terms of implementation. Reviewed from various aspects, it is definitely possible that the concept of smart city is also applied in the region with the status of regency. The preparation of smart city blueprint both region and municipality should be more prioritize the characteristics and local wisdom owned by the region. Particularly for regency, the concept of local wisdom for the implementation of smart cities definitely should consider the aspects of the region that is owned by different demography, more complex government structure with different population characteristics in each region. The extent of the regency is of course a challenge in the application of the concept of smart city in the regency.

Other aspects such as population, economic activity, and socio-cultural life are also important things to consider when a regency is going to implement the concept of smart city. Thus, the blueprints, as well as the smart city governance roadmap implemented in the regency, will be more precisely targeted according to their own spatial plan. 
Literature studies that have been conducted show many smart city conditions in various regions with their own uniqueness. Some have put forward the implementation of technology. There is also a focus on meeting the needs of an intelligent environment and how to build a smart society before the smart city is realized. Nevertheless, essentially the concept of smart cities can actually be implemented in non-urban areas. Efficiency related to smart cities must be more directed at what needs an area needs. Not just prioritizing technological sophistication. But it must be able to make the city livable and answer the local wisdom of each region.

\section{Conclusion}

Based on the results of literature studies conducted, it can be concluded that the implementation of smart cities should pay attention to the characteristics of the region. The characteristics of the municipality and regency allow the construction of a smart city concept blueprint adapted to the local wisdom and characteristics they possess. In addition, smart city implementation at this time has not been able to make the city habitable because it still put forward the utilization of technology as its base while the residents of the city are still out of focus to become smart people. Many newly built applications are limited to facilitate the activities of the residents of the city, yet lead to the actual needs to make a smart habitable city in accordance with the concept of the smart city itself. Applications built, even more, indicate making the city residents are lazy, unproductive and consumptive.

\section{Acknowledgments}

Acknowledgments are expressed to the Ministry of Research, Technology, and Higher Education who has funded this research with the scheme of Higher Education Superior Research/Penelitian Unggulan Perguruan Tinggi (PTUPT) for the budget year of 2018.

\section{References}

[1] Kalašová, A., Čulík, K., and Kubíková, S., 2018, Smart City - Model of Sustainable Development of Cities, Proceeding of XI International Science-Technical Conference Automotive Safety, pp. 1 - 5

[2] El-Khateeb, S., 2018, IoT Architecture a Gateway for Smart Cities in Arab World, Proceeding of $15^{\text {th }}$ Learning and Technology Conference (L\&T), pp. $153-160$

[3] Rachmawati, T., and Pertiwi, P.D., 2017, Smart Environment Program, Smart Way to Smart City, Policy \& Governance Review, Vol. 1, Issue 1, pp. 26-36

[4] Kumar, N.M., Goel, S., and Mallick, P.K., 2018, Smart Cities in India: Features, Policies, Current Status, and Challenges, Proceeding of IEEE International Conference on Technologies for Smart-City Energy Security and Power ICSESP-2018)

[5] Firmanyah, H.S., Supangkat, S.H., Arman, A.A., and Adhitya, R., 2017, Searching Smart City in Indonesia Through Maturity Model Analysis : Case Study in 10 Cities, Proceeding of The International Conference on ICT for Smart Society (ICISS)

[6] Goldberg, M., and Zhang, Z., 2018, A Cyber-Physical System Framework Towards Smart City and Urban Computing to Aid People with Disabilities, Proceeding of The 27th Wireless and Optical Communications Conference (WOCC2018)

[7] Arthy, D.K., Pingle, A., Dancy, S.G., and Sushmitha, V.R., 2017, Smart Device To Help People With Dementia, Proceeding of Third International Conference on Science Technology Engineering \& Management (ICONSTEM), pp. $202-206$ 
[8] Bryant, N., Spencer, N., King, A., Crooks, P., Deakin, J., Young, S., 2017, IoT and Smart City Services to Support Independence and Wellbeing of Older People, Proceeding of 25th International Conference on Software, Telecommunications and Computer Networks (SoftCOM)

[9] Daudpota, M.H., Sahito, A.A., Soomoro, A.M., and Channar, F.S., 2017, Giving Blind a Smart Eye : Designing and Modeling of Intelligent White Cane for Blind People, Proceeding of IEEE Global Humanitarian Technology Conference (GHTC)

[10] Kasthuri, R., Nivetha, B., Shabana, S., Veluchamy, M., and Sivakumar, S., 2017, Smart Device for Visually Impaired People, Proceeding of Third International Conference on Science Technology Engineering \& Management (ICONSTEM), pp. $54-59$

[11] Purnomo, F., Meyliana, and Prabowo, H., 2016, Smart City Indicators: A Systematic Literature Review, Journal of Telecommunication, Electronic and Computer Engineering, Vol. 8, No. 3, pp. 161 $-164$

[12] Tampubolon, L.P.D., 2016, Pemeringkatan E-Government Indonesia (PEGI) dan Pemanfaatan Teknologi Informasi Di DKI Jakarta, Jurnal Sistem Informasi (JSI), VOL. 8, NO. 2, pp. 1121 - 1132, in bahasa

[13] Basiri, M., Azim, A.Z., and Farrokhi, M., 2017, Smart City Solution for Sustainable Urban Development, European Journal of Sustainable Development (2017), Vol. 6, Issue 1, pp. 71-84

[14] Kumar, S., and Prakash, A., 2016, Role of Big Data and Analytics in Smart Cities, International Journal of Science and Research (IJSR), Vol. 5, Issue 2, pp. 12 - 23

[15] Monzon, A., 2015, Smart Cities Concept and Challenges: Bases for the Assessment of Smart City Projects, Communications in Computer and Information Science, Vol. 579, pp. 17-31

[16] Indrawati, Widodo, W., and Amani, H., 2018, Indicators to Measure a Smart Education: An Indonesian Perspective, Proceedings of the International Conference on Industrial Engineering and Operations Management, pp. 3486 - 3495

[17] Jabbar, M.A., and Aluvalu, R., 2017, Smart Cities In India:Are We Smart Enough?, Proceeding of International Conference On Smart Technologies For Smart Nation (SmartTechCon), pp. 1023 1026

[18] Nadapdap, N.Y., Alamanda, D.T., Prabowo, F.S., and Ayuningtyas, H.G., 2016, Measuring The Effectiveness Of Government Communication On Bandung Smart City (The Study On @Ridwankamil Twitter Account During The Period Of 16 September 2013 To 31 July 2015), IOSR Journal Of Humanities And Social Science (IOSR-JHSS), Vol. 21, Issue 4, pp. 72-79

[19] Hayati, A., Bararatin, K., Utami, A.S.P.R., Septanti, D., Santosa, H.R., Weichart, G., Valent, M.K., 2017, From Smart Living into Smart City: A Lesson from Kampung of Surabaya, Proceeding of UIA 2017 Seoul World Architects Congress, pp. 1 - 6

[20] Schleicher, J.M., Vögler, M., Dustdar, S., and Inzinger, C., 2016, Enabling a Smart City Application Ecosystem : Requirements and Architectural Aspects, IEEE Internet Computing, pp. 58 65

[21] Wu, S.M., Chen, Tc., Wu, Y.J., and Lytras, M., 2018, Smart Cities in Taiwan: A Perspective on Big Data Applications, Sustainability, Vol. 10, No. 106, pp. $1-14$

[22] Colldahl, C., Frey, S., and Kelemen, J. E., 2013, Smart Cities : Strategic Sustainable Development for an Urban World, Master thesis, School of Engineering, Blekinge Institute of Technology,Sweden

[23] IEEE, About Smart Cities. Accessible online:http://smartcities.ieee.org/about.html [2018-06-16] [24] Zelinka,T., Pribyl,O., and Lom, M., 2016, "Smart" as a key component of the sustainable city development, Systemics, Cybernetics and Informatics, Vol. 14, Number 5, pp. $16-21$

[25] Suri, N., Zielinski, Z., Tortonesi, M., Fuchs, C., Pradhan, M., Wrona, K., Furtak, J., Vasilache, D.B., Street, M., Pellegrini, V., Benincasa, G., Morelli, A., Stefanelli, C., Casini, E., and Dyk, M., 2018, Exploiting Smart City IoT for Disaster Recovery Operations, Proceeding of IEEE 4th World Forum on Internet of Things (WF-IoT), pp. $458-463$

[26] Gambın, A.F., Gindullina, E., Badia, L., and Rossi, M., 2018, Energy Cooperation for Sustainable IoT Services within Smart Cities, Proceeding of 2018 IEEE Wireless Communications and Networking Conference (WCNC): Special Session Workshops, pp. 387 - 392 
[27] Masato, T., Masayuki, M., and Hao, T., 2014, Energy Management with Battery System for Smart City, Proceedings of the 33rd Chinese Control Conference, pp. 8200 - 8203

[28] Talha, M., Upadhay, A., Shamim, R., and Beg, M.S., 2017, A Cloud integrated wireless garbage management system for Smart Cities, Proceeding of International Conference on Multimedia, Signal Processing and Communication Technologies (IMPACT), pp. 175 - 179

[29] Ziadi, A.R., Supriyono, B., and Wijaya, A.F., 2016, The Effectiveness of Information System in Public Complaint Service: An Implementation of E-Government based on Jakarta Smart City Applications, Global Journal of Management and Business Research:A Administration and Management, Vol. 16, Issue 8, pp. 52 - 57

[30] Leccese, F., Cagnetti, M., and Trinca, D., 2014, A Smart City Application: A Fully Controlled Street Lighting Isle Based on Raspberry-Pi Card, a ZigBee Sensor Network and WiMAX, Sensor, Vol. 14, pp. 24408-24424

[31] Revathy.M., Ramya.S., Sathiyavathi.R., Bharathi, B., and Anu, V.M., 2017, Automation of Street Light For Smart City, Proceeding of International Conference on Communication and Signal Processing, pp. $0918-0922$

[32] Latif, S., Afzaal, H., and Zafar, N.A., 2018, Intelligent Traffic Monitoring and Guidance System for Smart City, Proceeding of 2018 International Conference on Computing, Mathematics and Engineering Technologies - iCoMET 2018

[33] Gupta, V., Kumar, R., Srikanth, R.K., and Panigrahi, B.K., 2017, Intelligent Traffic Light Control for Congestion Management for Smart City Development, Proceeding of 2017 IEEE Region 10 Symposium (TENSYMP)

[34] Wong, S.F., Mak, H.C., Ku, C.H., and Ho, W.I., 2017, Developing Advanced Traffic Violation Detection System with RFID Technology for Smart City, Proceeding of 2017 IEEE International Conference on Industrial Engineering and Engineering Management (IEEM), pp. 334 - 338

[35] Mallissery, S., Pai, M.M.M., and Pai, R.M., 2017, Analysis of Vehicle Speed Limit and Air Pollution Load for Identifying Road Conditions in India: An Empirical Study for Smart City, Proceeding of 2017 IEEE International Conference on Smart Grid and Smart Cities, pp. 272 - 276

[36] Banach, M., and Dlugosz, R., 2017, Real-time Locating Systems for Smart City and Intelligent Transportation Applications, Proc. 30th International Conference On Microelectronics (MIEL 2017), pp. $231-234$

[37] Thomas, G., Alexander, G., and Sasi,P.M., 2017, Design of High PerformanceClusterbased Map for Vehicle Tracking of public transport vehicles in Smart City, Proceeding of 2017 IEEE Region 10 Symposium (TENSYMP)

[38] AL Farsi, W.A., and Achuthan, G., 2018, Analysis of Effectiveness of Smart City Implementation in Transportation Sector in Oman, Proceeding of 2018 Majan International Conference (MIC)

[39] Purwanda, I.G., Adiono, T., Situmorang, S., Dawani, F., Samhany, H.A., and Fuada, S., 2017, Prototyping Design of A Low-Cost Bike Sharing System for Smart City Application, Proceeding of 2017 The International Conference on ICT for Smart Society (ICISS)

[40] Xixi, L., Hua, Q., Hong, Z., Yinghua, H., 2015, The 5I model of Smart City: a case of Shanghai, china, Proceeding of 2015 IEEE First International Conference on Big Data Computing Service and Applications, pp. $329-332$

[41] Li, Y., Lin, Y., and Geertman, S., 2015, The development of smart cities in China, CUPUM 2015 , pp. $291.1-291.20$

[42] Hafez, H.A.A., 2017, Big Data in Smart Cites: Analysis and Applications in Arab World, Egyptian Computer Science Journal, Vol. 41, Issue 1, pp. 38 - 52

[43] Ministry of Urban Development Government of India, 2015, "Smart City: Mission Transformation", India

[44] ITU-T Technology Watch Report, 2013, "Smart Cities Seoul: a case study",Seoul.

[45] Senate Department for Urban Development and the Environment, 2015, "Smart City Strategy Berlin", Berlin 
[46] Effendi, D., Syukri, F., Subiyanto, A.F., Utdityasan, R.N., 2016, Smart City Nusantara Development through the Application of Penta Helix Model : A Practical Study to Develop Smart City based on Local Wisdom, Proceeding of 2016 International Conference on ICT For Smart Society, pp. $80-85$ 